\title{
Farmers' Perceptions on Climate Change: A Step toward Climate Change Adaptation in Sylhet Hilly Region
}

\author{
M. Kamruzzaman \\ Department of Agricultural Extension Education, Sylhet Agricultural University (SAU), Bangladesh
}

Copyright $@ 2015$ Horizon Research Publishing All rights reserved.

\begin{abstract}
The main objective of the study was to determine and describe the perception of climate change of farmers. The study was conducted at Sreemangal and Baralekha Upazilla of Moulovibajar district. Three villages from each upazilla were selected as the specific study location. A sample of 150 respondents $(20 \%)$ was randomly selected from a total population of 800 farmers. Data were collected from the sampled respondents throughout July-August, 2013 through interview schedule. Most of the farmers $(69.3 \%)$ perceived that climate change started between last 5 to 15 years. Almost half of the farmers (48.0\%) believe that environmental factor is responsible for climate change than supernatural factor. They felt that both rainy season and cold season delays to start but ends early. Mean duration of both seasons has been significantly reduced in recent past than long time ago. Hot season shows opposite scenario as it starts early but delays to end. Mean duration of hot season has been significantly increased in recent past compared to long time ago. Similarly, they believe that hotness has increased $(88.7 \%)$ and coldness has reduced $(60.0 \%)$. Farmers found a reduction in overall rainfall $(83.3 \%)$ and variation in wind speed, duration of strong wind. They felt the incidence of drought has been increased (73.3\%) and flood has been decreased (66\%). Level of education and access to extension services had significant association with their perceived cause of climate change. Farmers having more education and high access to extension service perceived environmental factor for climate change than supernatural factor and vice versa.
\end{abstract}

Keywords Farmers, Perception, Climate Change, Adaptation

\section{Introduction}

The impact of climate change on agriculture food production is global concerns and for that matter Bangladesh, where lives and livelihoods depend mainly on agriculture, is exposed to a great danger, as the country is one of the most vulnerable countries due to climate change [1]. In
Bangladesh, crop production will decrease $30 \%$ in 2100 . Production of rice $\&$ wheat will reduce $8.8 \%$, and $32 \%$ within 2050 respectively $[2,3]$. According to Gunter et. al. [4] the climate change literature is mostly focusing on Bangladesh's geographic location, Bangladesh's geo-morphological conditions, and Bangladesh's low level of development. The usual assumption is that the coastal area and the large river delta will be the most severely affected areas while the elevated parts in the north east (Sylhet region) of Bangladesh are generally considered to be far less affected by climate change.

Sylhet region is highly vulnerable to river flood, flash flood, intensive rainfall, and land slide. In the recent years, the frequency of flash flood has been increased. Tornado and hailstorm are also two important climate induced disasters for this region which damages crops, houses, trees and even human death. Intensive rainfall causes land slides and erosion in the hillocks area. Soil degradation, due to the sandification of arable land, is also seen as a hazard in this area as well as siltation of river and water bodies that enhance the strength of floods and provoke water logging.

According to Enete et. al. [5] much of climatic change agricultural research in Bangladesh has tended to concentrate on assessing the sensitivity of various attributes of crop systems (e.g. crop/livestock yields, pest, diseases, weeds etc) - the bio-physical aspects of food production, with little or no regard to the socioeconomic aspects. These partial assessments, most often consider climatic change effects in isolation, providing little insight into the level of awareness of the farmers on the issue, what and how they are doing to cope with climate change, etc. Wisner et. al. [6] reports that the vulnerability of agriculture is not determined by the nature and magnitude of environmental stress like climate change per se, but by the combination of the societal capacity to cope with and/or recover from environmental change.

According to Nyanga et. al. [7] technology adoption has been guided mainly by innovation-diffusion paradigm, economic constraint paradigm and adopter perception paradigm. The adopter perceptions paradigm posits that the adoption process starts with the adopters' perception of the problem and technology proposed [8]. This paradigm argues that perceptions of adopters are important in influencing 
adoption decisions [9]. Perceptions are context and location specific due to heterogeneity in factors that influence them such as culture, education, gender, age, resource endowments and institutional factors $[10,11]$. To better cope up and adopt strategies, technologies, it is the principal need to determine the perception of farmers' on climate change in hilly areas of Sylhet region.

In view of this context, the study was conducted with the following objectives; 1 . To assess the perception of framers' on climate change in Sylhet hilly region, 2. To identify the socio-economic profile of the farmers 3 . To determine the relationship of selected characteristics of the farmers with their perception on climate change.

\section{Methodology}

Location, population and sample: The study was conducted at Sreemangal and Baralekha Upazilla of Moulovibajar district. Three villages from each upazilla were selected as the specific study location. The selection was made on the basis of suggestions made by the Upazila Agriculture Officer (UAO), Sub-Assistant Agriculture Officer (SAAO), Union Parishad Members and Officials of respective upazila. An up dated list of all the farmers of the selected villages was prepared by the help of the SAAO and respective union parishad members. A total 800 farmers (one from each household) in the selected villages were considered as population of the study. About twenty percent of the population (i.e. 150 farmers) was randomly selected as the sample of the study. Purposive sampling was used in the selection of key informants and focus group discussants so as to have participants who are known to have opinions and experiences on the topics for discussion.

Variables of the study and their Measurement: Various characteristics of the farmers were considered as the independent variables of the study. The characteristics were level of education, year of farming experience, access to credit facilities, access to extension services and number of agricultural training received. Dependent variable farmers' perceptions on climate change consist of data on start of climate change, perception of causes of climate change, perception of changes in on-set and off-set of seasons, perception of changes in duration of season, coldness, hotness, drought, flood, rainfall and wind speed, perception of changes in mean duration of seasons in months.

Data collection and analysis: A questionnaire was prepared in order to collect related, valid and reliable information from the selected students. The questionnaire was carefully designed and prepared with open and closed forms of questions keeping the objectives of the study in mind. In order to give the final shape, the questionnaire was pre-tested with 25 respondents. Based on the pretest results necessary correction, modification, alternation and adjustment were made and then finalized the questionnaire. Data was collected during July-August 2013. The collected data was coded in numerical numbers, compiled, tabulated and analyzed using SPSS software keeping the objectives of study in mind. In order to categorize and explain the data, some statistical measures such as range, mean, percentage and standard deviation were used. To explore any relationship and association Chi-square test were used. Five percent $(0.05)$ level of probability was used throughout the study as the basis for statistical significant.

\section{Results \& Discussions}

\subsection{Socio-economic Profile of the Farmers}

Socio-economic profile of farmers is presented in Table 1. From the table it is found that farmers' mean of level of education was 4.62 with 3.96 standard deviation. Here, one-third of the framers can sign only and only $24.7 \%$ had education above primary level. In case of farming experience, the mean was 24.23 with 11.53 standard deviation. Majority of the farmers $(66.7 \%)$ had medium farming experience. The mean of agricultural training received was 1.16 with standard deviation 1.67. The proportion of farmers having no credit facilities was higher $(55.3 \%)$ than those had credit facilities (44.7\%). In case of access to extension services, $43.3 \%$ farmers had no access where as $33.3 \%, 18.7 \%$ and $4.7 \%$ farmers had low, medium and high access respectively.

Table 1. Socio-economic profile of the respondents

\begin{tabular}{|c|c|c|c|c|c|c|c|c|}
\hline \multicolumn{9}{|c|}{ Level of education } \\
\hline Min & Max & Mean & SD & $\begin{array}{c}\text { Can't sign } \\
(\%)\end{array}$ & $\begin{array}{c}\text { Can sign only } \\
(\%)\end{array}$ & $\begin{array}{c}\text { Primary } \\
(\%)\end{array}$ & $\begin{array}{c}\text { Secondary } \\
(\%)\end{array}$ & $\begin{array}{c}\text { Above secondary } \\
(\%)\end{array}$ \\
\hline 0 & 12 & 4.62 & 3.96 & 0.7 & 33.3 & 41.3 & 14.7 & 10.0 \\
\hline \multicolumn{9}{|c|}{ Farming experiences (year) } \\
\hline Min & $\operatorname{Max}$ & Mean & SD & & & $\mathrm{Me}$ & & High (\%) \\
\hline 2 & 60 & 24.23 & 11.53 & & & 66.7 & & 14.0 \\
\hline \multicolumn{9}{|c|}{ Agricultural training received } \\
\hline & & & & Min & $\operatorname{Max} \quad \mathrm{N}$ & SD & & \\
\hline & & & & 0 & 7 & 1.67 & & \\
\hline \multicolumn{9}{|c|}{ Access to credit facilities } \\
\hline & & & & & & & & \\
\hline & & & & & & & & \\
\hline \multicolumn{9}{|c|}{ Access to extension services } \\
\hline & & \multirow{2}{*}{\multicolumn{2}{|c|}{$\begin{array}{c}\text { Not at all (\%) } \\
43.3\end{array}$}} & Low $(9$ & \multicolumn{2}{|c|}{ Medium (\%) } & \multirow{2}{*}{\multicolumn{2}{|c|}{ High (\%) }} \\
\hline & & & & 33.3 & & & & \\
\hline
\end{tabular}




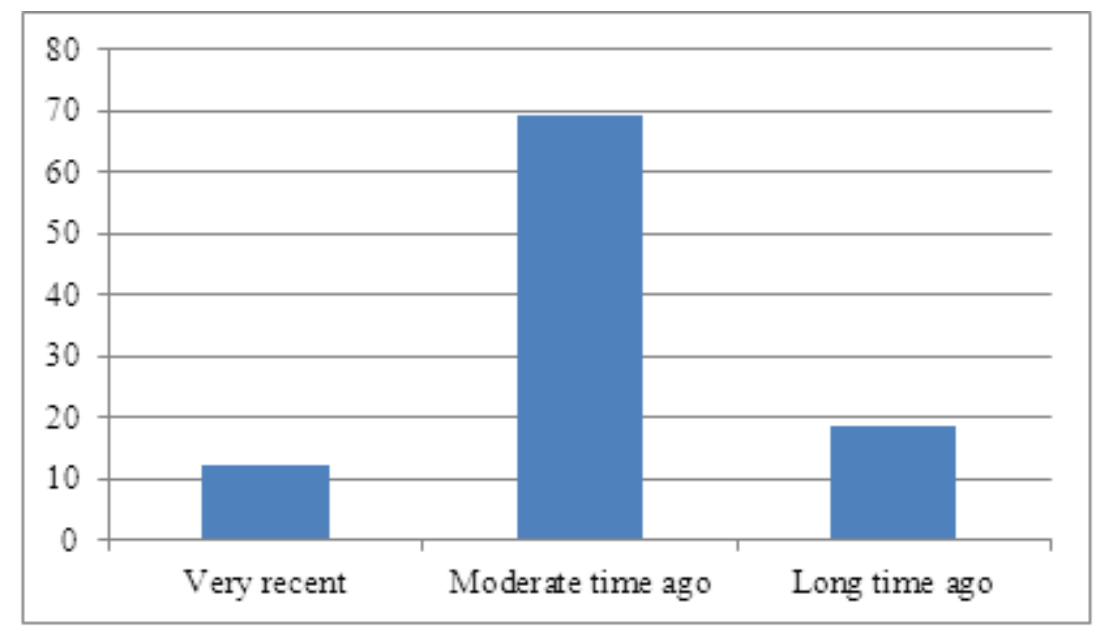

Figure 1. Bar diagram shows the farmers' percentage on perception of climate change start

\subsection{Farmers' Perception of Climate Change}

\subsubsection{Start of Climate Change}

The mean of climate change start perceived by farmers' was 9.53 year with standard deviation 5.23 as shown in figure 1. Majority of the farmers $(69.3 \%)$ believed that climate change started moderate time ago (5-15 yrs). Almost equal proportion of farmers perceived that it started very recent $(\leq 4 \mathrm{yrs})$ and long time ago ( $\geq 15 \mathrm{yrs})$. According to Akponikpè et. al. [12] more proportion of farmers in the Sahel identified the change of climate to have started between 20-30 years ago or more.

\subsubsection{Perceptions of causes of climate change}

Farmers' perceptions of causes of climate change are presented in Table 2. It is found that almost half proportion $(48.0 \%)$ of the farmers thought that climate change is caused by environmental factors. Only $28 \%$ respondents described it as supernatural factors and $24 \%$ had no explanation. Nyanga et. al. [7] found that $53.55 \%$ farmers believed in supernatural factor of climate change whereas $32.69 \%$ believed in environmental factor and $13.76 \%$ had no explanation.

Table 2. Farmers' perceptions of causes of climate change

\begin{tabular}{cc}
\hline Explanation & Percentage \\
\hline No explanation & 24.0 \\
Environmental factors & 48.0 \\
Supernatural factors & 28.0 \\
\hline
\end{tabular}

Data presented in the Table 3 indicates that perceived causes of climate change varied by their educational background as the computed chai square value of 26.305 was statistically significant at 0.001 level of probability. Where only $36.3 \%$ respondents having primary education thought environmental factor of climate change, $93.3 \%$ respondents thought it that have above secondary education. Respondents with above secondary education didn't perceive supernatural factor as a cause of climate change but 39\% respondents having primary education thought so. This finding is supported by Nyanga et. al. [7] that revealed the percentage of respondents with more secondary and higher level of education that cited environmental factors was significantly more than that of the less educated.

Table 3. Distribution of respondents according to their level of education and perceived causes of climate change

\begin{tabular}{ccccc}
\hline \multirow{2}{*}{$\begin{array}{c}\text { Level of } \\
\text { education }\end{array}$} & $\begin{array}{c}\text { No } \\
\text { explanation }\end{array}$ & $\begin{array}{c}\text { Causes of climate change } \\
\text { Environmental } \\
\text { factor }\end{array}$ & $\begin{array}{c}\text { Supernatural } \\
\text { factor }\end{array}$ & Total \\
\hline Primary & 33 & 41 & 39 & 113 \\
& $(29.2)$ & $(36.3)$ & $(34.5)$ & $(100)$ \\
Secondary & 2 & 17 & 3 & 22 \\
Above & $(9.1)$ & $(77.3)$ & $(13.6)$ & $(100)$ \\
secondary & 1 & 14 & 0 & 15 \\
Total & $(6.7)$ & $(93.3)$ & $(0)$ & $(100)$ \\
& $(24.0)$ & 72 & 42 & 150 \\
\hline
\end{tabular}

Chi square $=26.305 ; \mathrm{df}=4 ; \mathrm{P}<0.000$; Significant association

More than half (57.4\%) of the respondents having low access to extension services had no explanation or believed supernatural factor of climate change. On the contrary, high access to extension services ensures more than half proportion of respondents to felt environmental factor of climate change.

Table 4. Distribution of respondents according to their access to extension services and perceived causes of climate change

\begin{tabular}{ccccc}
\hline $\begin{array}{c}\text { Access to } \\
\text { extension } \\
\text { services }\end{array}$ & $\begin{array}{c}\text { No } \\
\text { explanation }\end{array}$ & $\begin{array}{c}\text { Environmental } \\
\text { factor }\end{array}$ & $\begin{array}{c}\text { Supernatural } \\
\text { factor }\end{array}$ & Total \\
\hline \multirow{2}{*}{ Low } & 34 & 49 & 32 & 115 \\
& $(29.6)$ & $(42.6)$ & $(27.8)$ & $(100)$ \\
Medium & 2 & 19 & 7 & 28 \\
& $(7.1)$ & $(67.9)$ & $(25.0)$ & $(100)$ \\
High & 0 & 4 & 3 & 7 \\
& $(0)$ & $(57.1)$ & $(42.9)$ & $(100)$ \\
Total & 36 & 72 & 42 & 150 \\
& $(24.0)$ & $(48.0)$ & $(28.0)$ & $(100)$ \\
\hline
\end{tabular}

Chi $\quad$ square $=10.241 ; \quad \mathrm{df}=4 ; \quad \mathrm{P}<5.000 ; \quad$ Significant association

Data presented in the Table 4 indicates that variation of 
perceived causes of climate change varied by their access to extension services as the computed chai square value of 10.241 was statistically significant at 0.005 level of probability.

\subsubsection{Perceptions of changes in the onset and offset of seasons}

Table 5 depicts the perception of changes in the onset and offset of seasons. It is seen that in case of rainy season, 78\% farmers believed that it delays to start and $73.3 \%$ thought offset comes early. Akponikpè et. al. [12] revealed that onset of the rainy season was perceived by farmers to be later nowadays conversely the season cessation was mentioned to be earlier in Sahel. Majority of the farmers felt that hot season comes early but delays to end. $64.7 \%$ farmers perceived that cold season delays to start and $63.3 \%$ thought offset comes early. Nyanga et. al. [7] in his study found no change in onset \& offset of hot season and no change in onset but delays in offset of cold season in Zambia.

Table 5. Farmers' perceptions of changes in the onset and offset of seasons

\begin{tabular}{ccccccc}
\hline \multirow{2}{*}{ Perceptions } & \multicolumn{2}{c}{ Rainy season } & \multicolumn{2}{c}{ Hot season } & \multicolumn{2}{c}{ Cold season } \\
& Onset & Offset & Onset & Offset & Onset & Offset \\
\hline $\begin{array}{c}\text { Comes } \\
\text { early (\%) }\end{array}$ & 14.7 & 73.3 & 77.3 & 14.7 & 30.7 & 63.3 \\
$\begin{array}{c}\text { Delays (\%) } \\
\text { No change }\end{array}$ & 78.0 & 17.3 & 14.7 & 76.0 & 64.7 & 31.3 \\
$(\%)$ & 7.3 & 9.4 & 8.0 & 9.3 & 4.6 & 5.4 \\
\hline
\end{tabular}

\subsubsection{Perception of changes in duration of season}

Farmers' perception of changes in duration of season is shown in Table 6. It is found that most of the farmers (80.7\%) believed that duration of rainy season reduced whereas only $7.3 \%$ and $12.0 \%$ believer of increased and no change respectively. In case of hot season, majority $(77.3 \%)$ of them thought that duration increased and $0.7 \%, 11.3 \%, 10.7 \%$ responded that don't know, reduced, no change respectively. Sixty two percent farmers felt that cold season duration reduced whereas $2.0 \%, 12.7 \%$ and $23.3 \%$ perceived don't know, no change and increased respectively. Mertz et. al. [13] revealed that in rural Sahel households generally agreed that cold period have become shorter, hot periods longer and a reduction in rainy season [12].

Table 6. Farmers' perception of changes in duration of season

\begin{tabular}{cccc}
\hline Perceptions & Rainy season & Hot season & Cold season \\
\hline Don't know (\%) & 0.0 & 0.7 & 2.0 \\
Reduced (\%) & 80.7 & 11.3 & 62.0 \\
No change (\%) & 12.0 & 10.7 & 12.7 \\
Increased (\%) & 7.3 & 77.3 & 23.3 \\
\hline
\end{tabular}

\subsubsection{Perception of changes in temperature, rainfall and wind}

Table 7 depicts the perception of changes in temperature, rainfall and wind. It is seen that, in case of temperature, farmers felt that hotness increased $(88.7 \%)$ and coldness reduced $(60.0 \%)$. Majority $(83.3 \%)$ of them found a problem of reduced rainfall. Studies in several other developing countries indicate that most farmers perceive temperatures to have become wormer and rainfall reduced over the past decade or two $[14,15,16,17]$. In case of wind speed, $24.0 \%, 35.3 \%, 17.3 \%$ and $23.4 \%$ farmers responded as don't know, reduced, no change and increased respectively. Farmers were divided by $39.3 \%, 36.7 \%, 13.3 \%$ and $10.7 \%$ as don't know, reduced, no change and increased respectively for the duration of strong wind.

\subsubsection{Perception of changes of extreme events}

Farmers' perception of changes of extreme events is presented in Table 8. It is found that most of the respondents $(66.0 \%)$ believed that the incidence of flood has reduced whereas $6 \%, 12.7 \%$ and $15.3 \%$ are believer of don't know, no change and increased respectively. In case of drought, majority $(73.3 \%)$ of the farmers thought it has increased and others were divided as don't know (5.3\%), reduced (14.7\%) and no change $(6.7 \%)$. Kemausuor et. al. [18] revealed that despite the location of farm, drought condition is more prevalent than flood. Drought condition on farms in low lands and hills has been relatively high.

Table 7. Farmers' perception of changes in temperature, rainfall and wind

\begin{tabular}{|c|c|c|c|c|c|}
\hline \multirow{2}{*}{ Perceptions } & \multicolumn{2}{|c|}{ Temperature } & \multirow{2}{*}{ Rainfall } & \multicolumn{2}{|c|}{ Wind } \\
\hline & Hotness & Coldness & & Wind speed & Duration of strong wind \\
\hline Don't know (\%) & 0.0 & 1.3 & 2.7 & 24.0 & 39.3 \\
\hline Reduced (\%) & 5.3 & 60.0 & 83.3 & 35.3 & 36.7 \\
\hline No change $(\%)$ & 6.0 & 13.3 & 8.7 & 17.3 & 13.3 \\
\hline Increased (\%) & 88.7 & 25.3 & 5.3 & 23.4 & 10.7 \\
\hline
\end{tabular}

Table 8. Farmers' perception of changes of extreme events

\begin{tabular}{ccc}
\hline Perceptions & Flood & Drought \\
\hline Don't know (\%) & 6 & 5.3 \\
Reduced (\%) & 66.0 & 14.7 \\
No change (\%) & 12.7 & 6.7 \\
Increased (\%) & 15.3 & 73.3 \\
\hline
\end{tabular}




\subsubsection{Perception of changes in mean duration of seasons}

Table 9 presents the perception of farmers' of changes in mean duration of seasons. From the table it is found that farmers perceived that the mean duration of rainy season has been reduced and the paired t-test indicates significant different of mean value of recent past (2.71) and long time ago (3.71). In case of duration of hot season, the mean value of recent past is 5.32 months and long time ago is 3.99 months which are also found significant different from each other in paired t-test. The mean duration of clod season decreased since the paired t-test shows significant different in the mean value of recent past (3.71) and long time ago (4.06).

Table 9. Farmers' perception of changes in mean duration of seasons (in months)

\begin{tabular}{cccc}
\hline & Rainy season & Hot season & Cold season \\
\hline Recent past & 2.71 & 5.32 & 3.17 \\
Long time ago & 3.71 & 3.99 & 4.06 \\
T value & $-0.99 \mathrm{~s}$ & $1.33 \mathrm{~s}$ & $-0.89 \mathrm{~s}$ \\
\hline
\end{tabular}

$\mathrm{s}=$ significantly different at $5 \%$ level

\section{Conclusions}

Majority of the farmers felt that climate has started to change between last 5 to 15 years. Almost fifty percent of the respondents believe in environmental factors to cause climate change. Most of the farmers perceive that both rainy season and cold season delays to start but ends very early. Opposite scenario found in hot season which starts early but delays to end.

Farmers' responses showed significant reduction in duration of both cold season and rainy season and significant increase in duration of hot season. As a consequence they felt an increase of hotness and decrease in coldness and overall rainfall. Farmers found variation in wind speed and duration of strong wind throughout the year.

Farmers felt that the intensity of drought has been increased and flood has been decreased. It would be worthy to mention that respondents having sound academic background and more access to extension services hold strong believe on environmental factor for cause of climate change over supernatural factor. These findings of perception would be effective to increase the awareness of climate change in hillock farming community. These findings would provide a benchmark for the policy maker to formulate need based extension strategy for climate change adaptation in hilly areas of Sylhet region and a local solution of a global problem.

\section{REFERENCES}

[1] Basak, J. K. 2012. Climate Change Impacts on Rice Production in Bangladesh: Results from a Model. Unnayan
Onneshan-The Innovators.

[2] Alam, M. 2004. Adverse Impacts of Climate Change on Development of Bangladesh: Integrating Adaptation into Politics and Activities. (CLACC Working paper No. 1, Bangladesh). Dhaka: Bangladesh Centre for Advanced Studies.

[3] Climate Change Cell. 2006. Climate Variability and Change in Bangladesh Impacts, Vulnerability and Risks. Dhaka: Climate Change Cell, Bangladesh Department of Environment.

[4] Gunter, G. B., Rahman, A. and Rahman, A. F. M. A. 2008. How Vulnerable are Bangladesh's Indigenous People to Climate Change? Bangladesh Development Research Center (BDRC).

[5] Enete, A. A., Madu, I. I., Mojekwu, J. C., Onyekuru, A. N., Onwubuya, E. A. and Eze, F. 2011. Indigenous Agricultural Adaptation to Climate Change: Study of Southeast Nigeria. African Technology Policy Studies Network. RESEARCH PAPER No. 6.

[6] Wisner, B., Blaikie, P., Cannon, T. and Davis, I. 2004 At Risk: Natural Hazards; People's Vulnerability and Disasters. $2^{\text {nd }}$ Edition. Routledge, London.

[7] Nyanga, H. P., Johnsen, F. H. and Aune, J. B. 2011. Smallholder Farmers' Perceptions of Climate Change and Conservation Agriculture: Evidence from Zambia. Journal of Sustainable Development, 4(4): 73-85.

[8] Adesina, A. A. and Zinnah, M. M. 1993. Technology Characteristics, Farmers' Perceptions and Adoption Decisions: A Tobit Model Application in Sierra Leone. Agricultural Economics, 9: 297-311.

[9] Prager, K. and Posthumus, H. 2010. Socio-Economic Factors Influencing Farmers' Adoption of Soil Conservation Practices in Europe. In T. L. Napier (Ed.), Human Dimensions of Soil and Water Conservation (pp. 203-223): Nova science publishers.

[10] Ervin, C. A. and Ervin, D. E. 1982. Factors Affecting the Use of Soil Conservation Practices: Hypothesis, Evidence and Policy Implications. Land Economics, 58(3): 277-292.

[11] Posthumus, H., Gardebroek, C. and Ruerd, R. 2010. From Participation to Adoption: Comparing the Effectiveness of Soil Conservation Programs in the Peruvian Andes. Land Economics, 86(4): 645-667.

[12] Akponikpè, P. B. I., Johnston, P. and Agbossou, E. K. 2010. Farmers' Perception of Climate Change and Adaptation Strategies in Sub-Saharan West-Africa. ICID+18, 2nd International Conference: Climate, Sustainability and Development in Semi-arid Regions, Fortaleza - Ceará, Brazil.

[13] Mertz, O., Mbow, C., Reenberg, A. and Diouf, A. 2009. Farmers' Perceptions of Climate Change and Agricultural Adaptation Strategies in Rural Sahel. Environmental Management, 43:804-816.

[14] Gbetibouo, G. A. 2008. Understanding Farmers' Perceptions and Adaptations to Climate Change and Variability: The Case of the Limpopo Basin, South Africa. International Food Policy Research Institute (IFPRI) Discussion Paper, Washington, DC. pp. 1-2.

[15] Dinar, A., Hassan, R., Mendelsohn, R. and Benhin, J. 2008. 
Climate Change and Agriculture in Africa: Impact Assessment and Adaptation Strategies. Earthscan, London. pp. 100-106.

[16] Mubaya, C.P., Njuki, J., Liwenga, E., Mutsvangwa, E. P. and Mugabe, F. T. 2010. Perceived Impacts of Climate Related Parameters on Smallholder Farmers in Zambia and Zimbabwe. Journal of Sustainable Development in Africa, 12(5):170-186.
[17] Deressa, T. T., Hassan, R. M. and Ringler, C. 2011. Perception of and Adaptation to Climate Change by Farmers in the Nile Basin of Ethiopia. The Journal of Agricultural Science, 149(1): 23-31.

[18] Kemausuor, F., Dwamena, E., Bart-Plange, A. and Kyei-Baffour, N. 2011. Farmers' Perception of Climate Change in the Ejura-Sekyedumase District of Ghana. ARPN Journal of Agricultural and Biological Science, 6(10):26-37. 